at that time had said: "You have depression and that's why you can't focus."

The next semester, I took a lighter load. I thought it would be easy. But I got a low score. I also wrote an internal grant that got funded, but I never saw the money. At that point, I didn't want to get up or out of bed. I started being absent from the lab. I couldn't bring myself to walk to that place. The worst part is that I ended up with a C. My grade-point average crashed. Then, when exams came, I failed miserably. I worried about my teaching-assistant position and losing that money. I panicked. I was sitting there crying and thinking my world had fallen apart.

I I called a counsellor and told them that I was considering self-harm. There is a law in that area that if you try to hurt yourself, they put you in the psychiatric hospital. The police came in and handcuffed me. I was just crying and repeating, over and over, "I got a C. I'm going to get kicked out." In the hospital, I was monitored 24/7. After two days, I was still crying.

Ten days after my first hospitalization, I was handcuffed again and put in the hospital again. Each time I was put in the hospital by the police, I was charged more than US $\$ 100$ - a huge expense for me. I contacted the other PhD programme to see if the people there would honour their funding offer from the previous year. They said no. I opened a bottle of pain medica-

"Reach out for help. Surround yourself with people who will show you, in this darkness, that you will make it."

\title{
Tell the stories in
} your science

\author{
Use principles of narrative fiction to inspire your \\ research papers, says Amanda C. Niehaus.
}

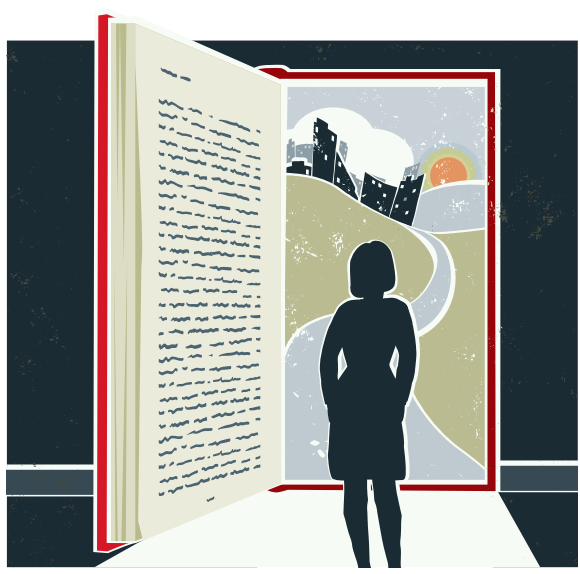

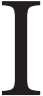
$\mathrm{n}$ the final month of my Australian Research Council fellowship at the University of Queensland in Brisbane, Australia, I published papers about sex-crazed marsupials, wrote grant applications and finished The Breeding Season, an as-yet-unpublished novel.

Yes, I wrote a novel - fiction founded on my science research. The story takes what I know about reproductive conflict in wild animals and explores it in humans. It's the hardest and most gratifying thing I have ever done.

I never expected to write about science in this way, mainly because I thought science and art were mutually exclusive. I learnt to avoid bias and passion, and to present my data as if seen through a microscope from a careful distance. Science is objective. Art, by contrast, is all about perspective, subjectivity and the confused experience that is life.

But creative writing can make scientific communication more powerful. We remember stories because our brains are wired to: we find them more interesting and are more likely to retell information if it's presented as narrative rather than exposition. In fact, papers written in a more-narrative style might be published in higher-impact journals and cited more often (A. Hillier et al. PLoS ONE 11, e0167983; 2016).

I've spent the past five years collecting data on ageing in northern quolls (Dasyurus hallucatus), small marsupials whose males essentially copulate themselves to death. As a scientist, I analyse, interpret and present the data with objectivity, according to the conventions of my field.

But I don't want to put distance between myself and my work, or between my work and the public. I want to show that the questions these animals face are universal - for example, how much time and energy to expend in making babies, and what that investment means for every other aspect of life. These issues define the choices we make about when and whether to have children, how to balance our careers with our families and how to spend our finite lives.

This is messy stuff. It's complex and complicated in ways not easily explored in a paper.

Last year, I published an essay called 'Pluripotent' (A. C. Niehaus Creative Nonfiction 64, 22-26; 2017), which examines the role of stem cells in the context of my experiences as a mother, researcher and cancer survivor, but also, metaphorically, as a woman in science. Creative writing can bring difficult concepts to life.

For me, compressing science into academic journals simply isn't enough. I'm frustrated by the need to reduce my ideas and experiments to publishable pieces while simultaneously ensuring that they are broadly relevant. I believe that the most exciting things happen at the fringe, the overlap, the moment we look at the same question through a different lens altogether. New ideas happen outside our comfort zone.

My research shows that among northern quolls, males and females lead different lives because of variations in how their bodies balance reproduction and longevity. How would these differences affect a reproductive relationship between humans? Their careers? Their ambitions? Isn't this what many of us really want to know?

In writing quoll biology into my novel and a short story, I discovered that artists and writers seek truth as much as scientists do. They embed facts with experiences to give them context and meaning. And stories deal not only with what is true, but also with what is possible. Through fiction, I may discover something about sex and death that my research did not tell me.

Where to start? Take a workshop in creative writing, curate an online gallery of inspiring images or invite writers to your next symposium. Stories are there in every book, movie and conversation - so notice them, and harness their energy to share your work.

Amanda C. Niehaus is a scientist and writer in Brisbane, Australia. 